\title{
Accelerating Sustainable Development Goals (SDGs) By Transformation of Civil Servant Management In Indonesia: Case Study In The Frontier, Outermost, And Least Developed Regions (3T)
}

\author{
Andhi Kurniawan ${ }^{1}$, Bonataon Maruli Timothy Vincent Simandjorang ${ }^{2}$ \\ Center for Program Fostering State Civil Apparatus Competency Development Policies, National \\ Institute of Public Administration Republic of Indonesia (Lembaga Administrasi Negara Republik \\ Indonesia/ LANRI), Jalan Veteran No. 10, Gambir, Jakarta, Indonesia, 10110 ${ }^{1}$, Center for State Civil \\ Apparatus Management Studies, National Institute of Public Administration Republic of Indonesia \\ (Lembaga Administrasi Negara Republik Indonesia/ LANRI), Jalan Veteran No. 10, Gambir, Jakarta, \\ Indonesia, $10110^{2}$ \\ \{andhisekar2212@gmail.com\}
}

\begin{abstract}
The government of Indonesia has stated fully commitment for SDGs by integration into development planning. In the centenary of independence, 2045, the government targets $5^{\text {th }}$ world's largest economy, by increasing role of outside Java to $48.2 \%$, and eastern Indonesia to $25.1 \%$ of national economy. The priority of inclusive development is directed for accelerating the frontier, outermost and least developed regions (daerah terdepan, terluar, dan tertinggal/ 3T). Mainstreaming SDGs in 3T regions cannot be separated from role of multi-stakeholder, especially civil servant (aparatur sipil negara/ ASN) as key enabler. This paper aims to develop the concept of transformation in $\mathrm{ASN}^{\text {'s }}$ management at $3 \mathrm{~T}$ areas in order to realize excellent competence and prime performance toward SDGs. This study uses qualitative methods through library research and interview. This research resulted in the holistic concept of ASN's management transformation in $3 \mathrm{~T}$ regions through needs assessment, competency development, career pattern, talent management, performance management, and welfare.
\end{abstract}

Keywords: Sustainable development goals (SDGs); frontier, outermost and least developed regions (3T); civil servant (ASN)

\section{Introduction}

The 70th General Assembly of the United Nations (UN) at New York, United States, September 2015, became one of the crucial moments that colored the global development agenda. 193 world leaders were present to agree on a new round of universal development action plans formulated in the document Transforming Our World: the 2030 Agenda for Sustainable Development which contains 17 goals and 169 targets that are valid from 2016 to 2030 [1]. This document is known as the Sustainable Development Goals (SDGs). The SDGs are a continuation of the Millennium Development Goals (MDGs) agenda initiated at the beginning of the 21 st century.

The Government of the Republic of Indonesia (GOI) has also expressed its commitment to the SDGs agenda which is a roadmap for the global development agenda until 2030. Real 
involvement from Indonesia in conceptualizing the framework up to financing the implementation of the SDGs agenda has been started since 2012 including: members of the CoChair High Level Panel of Eminent Persons; one of the Co-Chairs in drafting the concept of Global Partnership (Global Partnership); one of 30 countries that are members of the Open Working Group (OWG) on SDGs; and the Expert Forum for the preparation of the Concept of Financing for Sustainable Development [2].

Indonesia has become a pioneer country in mainstreaming the SDGs agenda with the issuance of Presidential Regulation Number 59 of 2017 concerning the Implementation of Achieving the SDGs. The SDGs agenda is a strategic element in the National Medium-Term Development Plan (Rencana Pembangunan Jangka Menengah Nasional/RPJMN) 2015-2019, 2020-2024 until the last agenda that has just been formulated, namely the Indonesia Vision 2045. In 2045, exactly a hundred years of independence, GOI targets to accelerate the achievement of the the nation's goals as stated in the Preamble to the 1945 Constitution. No half-hearted, Indonesia is expected to become a developed country with a high monthly per capita income of Rp. 27 million, become top five world economic powers, poverty is close to zero percent ( $\%)$, and the role of the economy outside Java is more inclusive to $48.2 \%$.

GOI commitments at global and national levels are not in line with the de facto implementation of the SDGs which began in 2016. In the last six years there has been no significant change (stagnation). Based on the SDGs Index Score which collects the achievement of the 17 SDGs targets, Indonesia is still ranked 97th out of 165 countries that have been included in the 2021 assessment, with a score of 66.34 as in Figure 1. Indonesia's position is even far behind other ASEAN countries, Vietnam, and the G20 country, China [3].

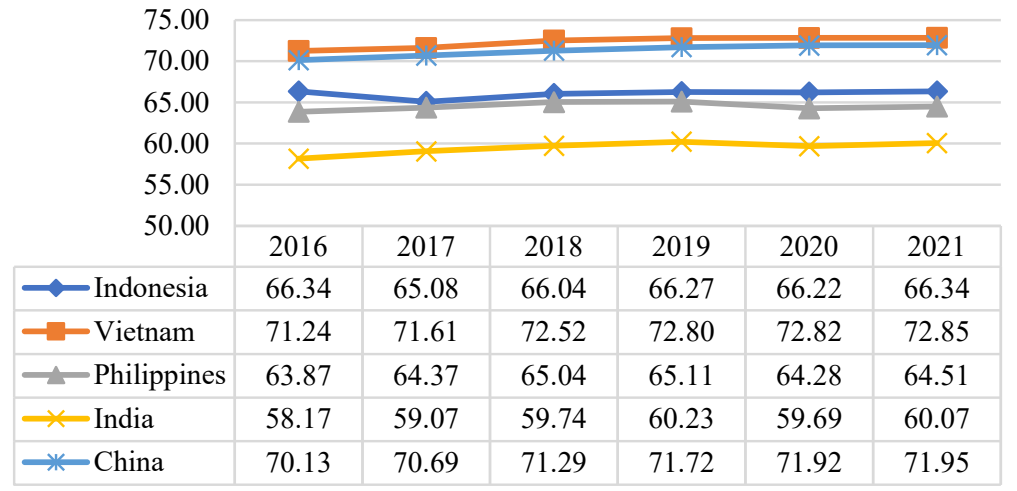

Fig. 1. SDGs Index Score 2016-2021.

The implementation progress of each of the 17 goals, none of them are in the green category (goal achievement). Table 1 shows that nine goals are still in the red category (major challenges), namely hunger, health, water and sanitations, innovation and infrastructure, inequalities, sustainable cities and communities, life below water, life on land, and peace and justice. Five goals have stagnated, namely: sustainable cities and communities, climate action, life below water, life on land, and partnership for the goals. Huge homework awaits GOI to be able to accelerate the achievement of the SDGs agenda which is only less than a decade away. 
Table 1. Implementation of SDGs in Indonesia

\begin{tabular}{|c|c|c|c|c|}
\hline Goals & Implementation & Trend & & Legends \\
\hline No Poverty & orange & $\underline{x}$ & green & Goal Achievement \\
\hline 2. No Hunger & red & $\underline{1}$ & yellow & Challenges remain \\
\hline 3. Good Health & red & $\underline{x}$ & orange & Significant challenges \\
\hline 4. Quality Education & yellow & $\bar{\imath}$ & red & Major challenges \\
\hline 5. Gender Equality & orange & $\underline{7}$ & & \\
\hline $\begin{array}{l}\text { 6. Clean Water and } \\
\text { Sanitations }\end{array}$ & red & $\bar{\uparrow}$ & $\uparrow$ & $\begin{array}{l}\text { On track or maintaining } \\
\text { achievement }\end{array}$ \\
\hline 7. Renewable Energy & orange & $\underline{ }$ & $\underline{\nearrow}$ & Moderately Increasing \\
\hline $\begin{array}{l}\text { 8. Good Jobs and } \\
\text { Economic Growth }\end{array}$ & orange & $\bar{\uparrow}$ & $\rightrightarrows$ & Stagnating \\
\hline $\begin{array}{l}\text { 9. Innovation and } \\
\text { Infrastructure }\end{array}$ & red & $\underline{ }$ & $\downarrow$ & Decreasing \\
\hline 10. Reduce Inequalities & red & & & \\
\hline $\begin{array}{l}\text { 11. Sustainable Cities } \\
\text { and Communities }\end{array}$ & red & $\rightrightarrows$ & & \\
\hline $\begin{array}{l}\text { 12. Responsible } \\
\text { Consumption }\end{array}$ & yellow & & & \\
\hline 13. Climate Action & yellow & $\rightrightarrows$ & & \\
\hline 14. Life Below Water & red & $\Rightarrow$ & & \\
\hline 15. Life on Land & red & $\rightrightarrows$ & & \\
\hline 16. Peace and Justice & red & $\bar{x}$ & & \\
\hline $\begin{array}{l}\text { 17. Partnership for the } \\
\text { Goals }\end{array}$ & orange & $\rightrightarrows$ & & \\
\hline
\end{tabular}

Heads of state and government that agreed on the SDGs, including the GOI, have affirmed their shared commitment to eradicating poverty, eliminating hunger, improving health quality, enhancing education, and reducing inequality. This development agenda also promises the spirit that no one will be left behind. It was explained that everyone from all type of groups would participate in implementing and feeling the benefits of the SDGs, by prioritizing the most marginalized groups [4].

The spirit of inclusiveness in the SDGs agenda is in line with the national development agenda formulated by GOI to not only focus on sectoral aspects but also on spatial aspects, one of which is the development of the frontier, outermost and least developed regions (daerah terdepan, terluar, dan tertinggal/ 3T) as part of the localized SDGs agenda at the micro and subnational level. Spatial issues are also an important agenda in continuing the unfinished MDGs agenda, such as equitable quality education in all regions, especially in 3T areas, and reducing disparities in the quality of child health services between regions, especially in $3 \mathrm{~T}$ areas [5].

$3 \mathrm{~T}$ areas suddenly become trending topic in the national news after the publication of the Nawacita agenda in 2014 which was declared by President Joko Widodo, by building the nation from the outskirts (remote areas). By using the Google Trends application, big data can be utilized to obtain fast and free information related to search trends on Google that discuss 3T regionals issues. With a span of more than fifteen years starting from January 1, 2005 to June 2021, Figure 2 shows that the search trend with the keyword $3 \mathrm{~T}$ areas has been widely discussed since 2014 and the trend is increasing from year to year until 2021 [6]. The issue of the 3T areas has attracted public attention. 


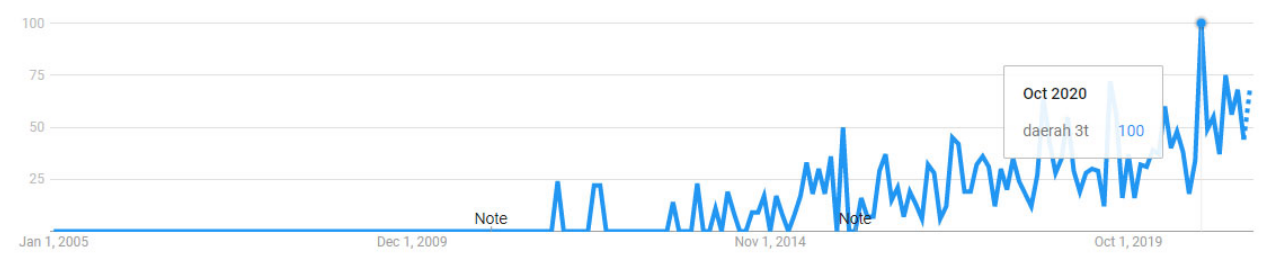

Fig 2. Search trends on Google regarding $3 \mathrm{~T}$ areas in Indonesia.

The acceleration of $3 \mathrm{~T}$ regionals development is GOI's excellent agenda to reduce inequality and ensure equity. In the RPJMN 2020-2024, there are five main targets that are set in accelerating national development in the $3 \mathrm{~T}$ regions by the end of 2024, namely: (1) The number of sub-districts in priority locations for state borders (Lokasi Prioritas/Lokpri) whose welfare and governance is improved from 187 to 222; (2) The average value of the Border Area Management Index (Indeks Pengelolaan Kawasan Perbatasan/IPKP) in 18 National Strategic Area Centers (Pusat Kawasan Strategis Nasional/PKSN) is 0.52; (3) The number of least developed districts (Kabupaten) from 62 to 25; (4) The percentage of poor people in least developed areas is 23.5-24\%; and (5) Average Human Development Index (HDI) in least developed areas from 58.11 to 61.7-62.2 [7].

To accelerate the development of $3 \mathrm{~T}$ regions, there are at least four required capacities, namely: (1) fiscal; (2) science and technology; (3) facilities and infrastructure; and (4) bureaucracy [8]. Bureaucratic machines are the state civil aparatus (aparatur sipil negara/ASN), both civil servants (pegawai negeri sipil/PNS) and government employees with work agreements (pegawai pemerintah dengan perjanjian kerja/PPPK) are required to act as catalysts. Nine years is a very short time, so ASN with prime competence and professionalism is needed to oversee the national and global development agenda implemented in the 3T areas. ASN management problems still plague the $3 \mathrm{~T}$ areas, including low competence and performance, incompatibility of ASN educational background/skills with regional needs and leading sectors, welfare disparities, limited fiscal space in the regions, and the lack of technical staff (specialist) outside of teachers and health workers [9].

Increasing ASN work motivation is the key in public services to achieve the post-2015 development agenda, including the SDGs. Human resource management (HR) policies that do not prioritize the principle of incentives will affect the morale and performance of ASN which then has implications for the quality of public services. Low motivation is one of the main factors for the failure of public services in the health and education sectors in Africa such as Botswana and South Africa. Their civil servants working in remote areas went on strike in 2007 demanding higher wages. This is also the case in the UK, where $70 \%$ of working civil servants feel that their morale is at an all-time low. They feel they are not supported by the work environment such as: quality leadership, incentives, career clarity, and appreciation for the ASN profession [10].

Transforming the management of ASN is needed as an important part of accelerating the SDGs agenda in the $3 \mathrm{~T}$ areas. The one size fits for all policy model needs to be abandoned because it is not relevant to the different needs and conditions of ASN from one agency to another, central and regional governments, and between local governments. Article 132 of Law number 5 of 2014 concerning ASN states that ASN policies and management are carried out by taking into account the specificities of certain regions and citizens with special needs. Certain regions in question are regions that have special autonomy, least developed regions, border areas, conflict areas, remote areas, and special regions. However, until now there has been no 
affirmative action policy issued to operationalize professional ASN management by prioritizing the principles of fairness and feasibility in the 3T area.This article aims to develop the concept of transformation in ASN's management at $3 \mathrm{~T}$ areas in order to realize excellent competence and prime performance toward SDGs.

\section{Literature Review}

Public sector human resource management (HRM) in remote areas is a serious challenge for many governments. There are HRM strategies for addressing difficulties in attraction and retention. First, the analysis of the factors determining attraction and retention. The knowledge about these factors is quite well developed include higher rates of remuneration, more satisfying working conditions, a safer working environment and better educational and career development opportunities, as well as broader factors such as higher quality of life, freedom from political persecution, freedom of speech and educational opportunities for children. Second, the identification of HRM strategies, usually a bundle of strategies to respond appropriately to the problems. The type of strategies for improving attraction to and retention in remote rural areas fall into four broad categories: (1) recruitment and training for rural practice; (2) the use of incentives and compulsory services; (3) improving working conditions; and (4) improving living conditions [11].

Welfare conditions also play important role to motivate employees in which will have implications for improving employee performance and at the same time it is expected to improve organizational performance. Employee welfare can be interpreted as the creation of happiness, comfort, satisfaction and improving the quality of life of employees due to various services, benefits, and facilities offered by the organization apart from salary with the aim of increasing work motivation and employee performance [12]. Employee welfare could define as complementary remuneration, both material and/or non-material, provided based on policy with the aim of maintaining and improving the physical and mental conditions of employees so that their productivity increases [13].

Welfare is considered to be able to motivate employees and in the end will have implications for improving employee performance and at the same time is expected to improve organizational performance. Incentives can generally be understood as rewards from organizations for the performance of their employees [14]. Incentives are various tools or techniques used to meet employee needs, to ensure employee job satisfaction and at the same time realize organizational goals. Incentives are related to financial and moral incentives [15]. The main goals of incentive is to compensate the high performing employee, to motivate the apparatus to perform excellent and to retain the employee avoiding the need for expensive recruitment and training [16].

Affirmative actions to enhance performance of civil servants through compensation and rewards has several components at specific conditions of regions as the Table 2 below shows, the combination package of financial and nonfinancial inventive [17][18].

Table 2. Compensation and Reward Components for Civil Servants

$$
\text { Type of Incentives }
$$

1. Non-Financial Rewards

- Talent pool, promotion, fast track at international or national level

- Priority for competency development (scholarship, training, coaching, etc) 


\begin{tabular}{|c|c|}
\hline Type of Incentives & Rewards \\
\hline & $\begin{array}{l}\text { Talent mobility, rotation, departmental } \\
\text { enrichment } \\
\text { Work-life balanced program, occupational } \\
\text { health/counselling, holiday/vacation, } \\
\text { recreational facilities, sabbatical, study leave } \\
\text { - Flexible reward (point-based reward) }\end{array}$ \\
\hline 2. Financial & $\begin{array}{l}\text { Pay, incentives, performance allowance, } \\
\text { bonus } \\
\text { Direct financial benefits: pensions, } \\
\text { illness/health/accident/life insurance, } \\
\text { clothing/accommodation allowance, travel } \\
\text { allowance, childcare allowances } \\
\text { Indirect financial benefits: subsidized } \\
\text { meals/clothing/accommodation, subsidized } \\
\text { transport, childcare subsidy } \\
\text { - Loan facility }\end{array}$ \\
\hline
\end{tabular}

Various empirical studies related to the welfare of ASN have been carried out in Indonesia with a focus on medical personnel in eastern Indonesia. Financial aspects such as salary, additional income incentives, housing, vehicles; and non-financial aspects such as competency development (workshops, etc.), the working environment is an essential requirement for the apparatus in the affirmative area [19], [20].

Empirical studies abroad also enrich the literature related to the welfare of ASN in the 3T area. In China, the salary increase is faster, about 3\% higher than the central government, border allowances, housing subsidies, health insurance, career development (positions, etc.) [21]. Lehmann (2008) also highlighted the case of ASN welfare in Zambia where the policy incentive package for medical personnel was in the form of financial support (benefits), accommodation renovation, children's school fees, vehicle/housing loans, and support for further competency development In Australia, the government provides an annual incentive bonus; location allowance per month; annual vacation leave; isolated concession annual leave; annual roundtrip airfare [22].

The UNDP Global Center for Public Service Excellence (2014) examined the case of the South African government provides salary increases; special skills and rural allowance (scarce skills and rural allowance); sponsorship for education; health insurance; additional period of service/retirement age; spouses are also given jobs to increase income (spousal employment). In Pakistan, transportation allowances are provided in the form of an annual round-trip airfare (including family), and a one-level promotion [23]. Even in Japan, there has been more detail in providing incentives for ASN welfare with a typology of area allowances (wide, remote, and cold areas); hardship duty allowances [24].

\section{Research Methods}

This research was conducted using an exploratory qualitative descriptive method through a library research and interviews. Descriptive study that performed the analysis with the way the system presents data, so it can be more easily understood and inferred whereas exploratory 
study is the kind of research that aims to discover something new in the form of a symptom grouping, the facts and circumstances. In the context of this research, the data from in-depth interviews with stakeholders related to $3 \mathrm{~T}$ areas, then identify and reduce the data. Explorative descriptive research aims to describe the state of a phenomenon, in this study it is not intended to test certain hypotheses but only describes what a variable, symptom or situation [25].

In this study, as a preparation stage, data and information are needed regarding data on targets and development achievements in the 3T area; and the number, type and distribution of civil servant as well as civil servant management policies working in 3T areas. The data and information needed in this activity include the following: (a) data and information regarding development targets and achievements in the 3T areas. This secondary data was obtained from the Ministry of National Development Planning (BAPPENAS), Ministry of Rural, Development of Least Developed Regions, and Transmigration, National Border Management Agency (BNPP) and medium term national development plan (RPJMN), Central Statistics Agency (BPS); (b) data on the type, number and distribution of civil servant in the $3 \mathrm{~T}$ areas. This secondary data was obtained from State Civil Servant Agency (BKN); and (c) Data and information regarding civil servant management policies in the $3 \mathrm{~T}$ areas. This data and information can be obtained from the Ministry of State Administrative and Bureaucratic Reform (KemenPANRB).

The data and information above are used as initial material to identify problems and materials to conduct in-depth interviews with resource persons. The more data obtained, the sharper the problem identification obtained. To find the right data, the researcher prioritizes the emic perspective, meaning that it is concerned with the views of the informant, namely how he views and interprets the object being studied. Data precision is prioritized at this stage.

\section{Results and Discussion}

\subsection{T Areas Overview}

The $3 \mathrm{~T}$ regionals development agenda is an important process with many portraits of strategic issues that are part of the national development agenda, RPJMN 2020-2024. Reviewing back to the previous development agenda, there is Presidential Regulation Number 131 of 2015 concerning the Determination of Least Developed Regions for 2015-2019 which stipulates a number of 122 Least Developed Regions. The achievements of the five-year development in the 2015-2019 period showed significant results in alleviating underdeveloped regions, where 62 regencies have been eradicated.

This achievement was then followed up with the establishment of a new legal principals in the development agenda of least developed regions for the next five years. Through Presidential Regulation Number 63 of 2020 concerning the Determination of Least Developed Regions for 2020-2024, 62 districts are set for the 2020-2024 period. Then there are also 222 subdistricts that have been designated as priority locations for state border areas, including 37 Outermost Small Islands (Pulau-Pulau Kecil Terluar/PPKT) and 18 National Strategic Activity Centers (PKSN) spread over 54 local governments as in Figure 3. The priority location interventions are directed at the aspects of fulfilling basic services, basic infrastructure and connectivity within the subdistrict, as well as governance. 


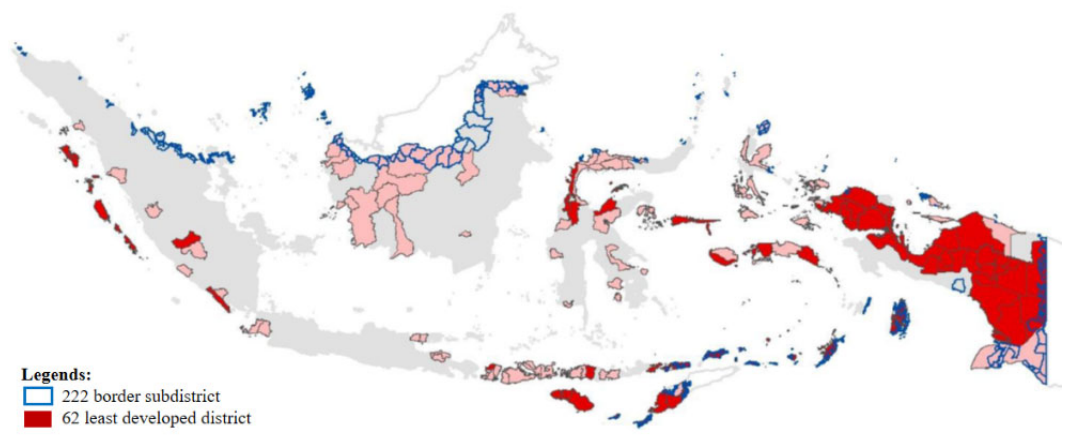

Fig 3. 3T areas distribution map.

The limited availability of adequate public service infrastructure is also a problem in the $3 \mathrm{~T}$ areas. Basic services such as education, health, and government administration are still not equally distributed and are able to provide optimal services for the people of the $3 \mathrm{~T}$ areas. In addition, ASN who carry out the function as public servants also do not get basic facilities and adequate government supporting infrastructure.

Based on the Table 3, the average distance to reach Inpatient and Non-Inpatient Health Centers in the least developed areas is $33.2 \mathrm{Km}$ and $30.1 \mathrm{Km}$, respectively. This means that the distance is three times longer than the average distance for the same health facilities in developed areas. The average distance traveled by the community in accessing the services of a sub-health center in least developed areas is $21.9 \mathrm{~km}$. It also means that the distance is equivalent to three times longer than the same health facilities in developed areas.

Table 3. Average Distance to Health Center Health Facilities in Disadvantaged Areas (Km)

\begin{tabular}{lccc}
\hline \multicolumn{1}{c}{ Districts } & $\begin{array}{c}\text { Inpatient Health } \\
\text { Center }\end{array}$ & $\begin{array}{c}\text { Health Center Without } \\
\text { Hospitalization }\end{array}$ & $\begin{array}{c}\text { Auxiliary Health } \\
\text { Center }\end{array}$ \\
\hline $\begin{array}{l}\text { Least Developed } \\
\text { Regions }\end{array}$ & 33.17 & 30.07 & 21.88 \\
$\begin{array}{l}\text { Developed } \\
\text { Regions }\end{array}$ & 11.22 & 10.91 & 6.76 \\
National & 16.48 & 15.33 & 10.42 \\
\hline
\end{tabular}

By observing the Table 4, the needs of least developed areas to access and enjoy education also have to cover a distance of two until three times longer than in developed regions. Referring to the Minimum Service Standards (Standar Pelayanan Minimal/SPM) in the field of education, the distance to primary school (sekolah dasar/SD) is $3 \mathrm{Km}$, and junior high school (sekolah menengah pertama/SMP) is $6 \mathrm{Km}$, so the distribution of educational facilities and infrastructure also needs to be continuously improved. In addition, the average length of schooling in underdeveloped areas is also lower than in developed areas. This problem, of course, needs to be resolved immediately, one of which is equal distribution of educational infrastructure.

Tabel 4. Education Services in Least Developed Areas

\begin{tabular}{|c|c|c|c|}
\hline Education Services & Least Developed Areas & $\begin{array}{c}\text { Developed } \\
\text { Areas }\end{array}$ & National \\
\hline \multicolumn{4}{|l|}{ Average Distance to School (Km) } \\
\hline SD & 6.99 & 2.43 & 3.14 \\
\hline
\end{tabular}




\begin{tabular}{|c|c|c|c|}
\hline SMP & 13.37 & 4.11 & 6.64 \\
\hline SMA & 21.35 & 7.59 & 11.81 \\
\hline \multicolumn{4}{|c|}{ Number of Educational Infrastructure } \\
\hline $\mathrm{SD}$ & 34,471 & 96,618 & 131,089 \\
\hline SMP & 7,296 & 13,578 & 20,875 \\
\hline SMA & 1,954 & 4,068 & 6,022 \\
\hline \multicolumn{4}{|l|}{ Educational Participation } \\
\hline Average School Age (Years) & 6.69 & 8.44 & 7.93 \\
\hline Literacy Rate $(\%)$ & 82.67 & 95.13 & 92.99 \\
\hline
\end{tabular}

The infrastructure of local government agencies such as sub-district offices in the 3T areas also needs attention. Out of 187 sub-districts in priority locations, there are 141 offices that are in good condition, 34 offices require renovation, and 12 offices are categorized as not yet feasible because there are no physical offices. Likewise, in the infrastructure of the Rural/Ward Government offices, out of a total of 1,675 Rural/Ward Government agencies, there are 1,034 Rural/Ward Governments that already have a physical office, and the remaining 19\% do not yet have an office or are categorized as damaged.

In the context of the financial budget in supporting the provision of public service infrastructure, the level of dependence of lagging regions on the central government tends to be higher. The average percentage of balancing funds to the total local government budget in least developed regions is $24 \%$ higher than in developed regions. Dependence on balancing funds from the central government tends to be greater in eastern Indonesia than in western Indonesia.

The geographical condition of the $3 \mathrm{~T}$ area which can be said to have special characteristics becomes a challenge for the community to access public services from the government. This is also a challenge for government in an effort to bring public services closer to the community. In the national border areas, several segments of the land and sea borders have not been completed. The border area can also be said to be not completely safe with cases of violation of state borders and cross-border violations still occurring.

The socio-economic conditions of the community in the $3 \mathrm{~T}$ areas require a continuous approach and facilitation. When comparing the socio-economic conditions of the people of Indonesia's border areas with neighboring countries, Malaysia and Singapore. The inequality that occurs can cause social jealousy and this can potentially lead to the degradation of the national spirit (nationalism). In general, the socio-economic conditions of border communities are still low. This can be indicated by the number of target households which is still high and the human development index (HDI) which is still low, even though the potential for resources is quite large both in land and sea border areas.

\subsection{ASN Outlooks in $3 T$ Regions}

There are a total of 182,697 civil servants (PNS) spread over 62 least developed district governments and 28 central government agencies working in the $3 \mathrm{~T}$ area as in Figure 4 . The number consists of $15 \%$ structural officers, $40 \%$ functional officials (nonmanagerial tasks), and $45 \%$ are administrative staff. In addition, there are 7,506 civil servants in 222 border subdistricts spread over 40 district governments and 35 central government agencies. The number of ASN in the border sub-districts consists of $24 \%$ structural officials, $21 \%$ functional officials, and 55\% are administrative staff. ASN employees, both PNS and PPPK in central and regional agencies on duty at Location $3 \mathrm{~T}$ are officers of the national border post (PLBN), head of PLBN, 
custom, immigration, quarantine, security (CIQS), quarantine, customs excise, migration, security, medical personnel and teachers working in public service centers, sub-district officers (camat and personels), rural/ward apparatus, etc [26].
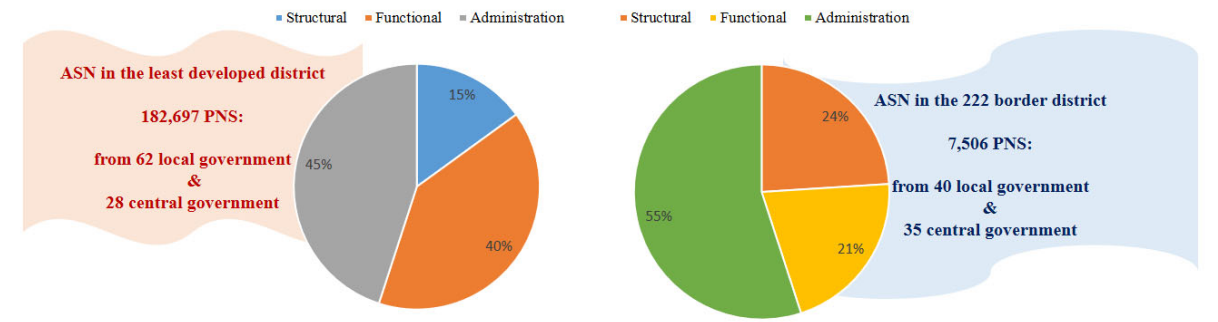

Fig 4. Composition of ASN in the 3T Regions as of October 2020.

Equitable distribution of human resources in the 3T areas is still an obstacle in realizing optimal public services. The limited quantity, quality, and suitability of the needs of medical personnel, education personnel, local government apparatus and rural governments need special attention to gradually overcome the inequality that exists in the $3 \mathrm{~T}$ areas. In the health sector, for example, the majority of officers who work as doctors and midwives are still concentrated in sub-districts located in the district capital, which are generally more crowded and developed than sub-districts that are far from the district capital.

For example, in South Central Timor Regency, East Nusa Tenggara Province, as shown in the Figure 5, it shows that the distribution of doctors and midwives is still concentrated in Soe City, which is a sub-district located in the capital of South-Central Timor Regency. When viewed nationally, only $6 \%$ of ASN health workers are placed in least developed regions, with the majority $94 \%$ of ASN health workers being placed in no least developed Regions. The disparity in the number of ASN health workers in least developed regions and no least developed regions is seen in almost all island regions in Indonesia. The disparity in the number of ASN health workers is highest on the islands of Sumatera and Sulawesi.

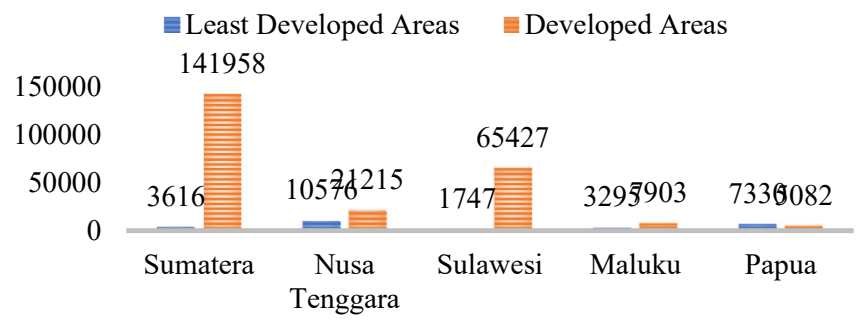

Fig 5. Distribution of the Number of Health Workers in Least Developed Areas and Developed Areas per Island Region.

In the field of education is also not much different from the conditions in the health sector. The problem also lies in the even distribution of teachers or teaching staff. The majority of human resources for apparatus who work as teachers or educators are still concentrated in the capital subdistricts of underdeveloped regions. This is almost the case at all levels of education units. For example, in the Gunung Bintang District, Papua Province, it shows that the distribution of teachers is still concentrated in Oksibil District, which is a sub-district located in 
the capital of the Bintang Mountains Regency. When viewed nationally, the distribution of the number of teachers in least developed areas and nonleast developed areas also experiences inequality. Nationally, $93 \%$ of ASN who work as teachers are placed in nonleast developed regions, with only $7 \%$ of ASN who carry out the function of education services in underdeveloped regions. The disparity in the number of teachers in least developed areas and nonleast developed areas is seen throughout the island. The highest inequality is on the islands of Sumatera and Sulawesi as in Figure 6.

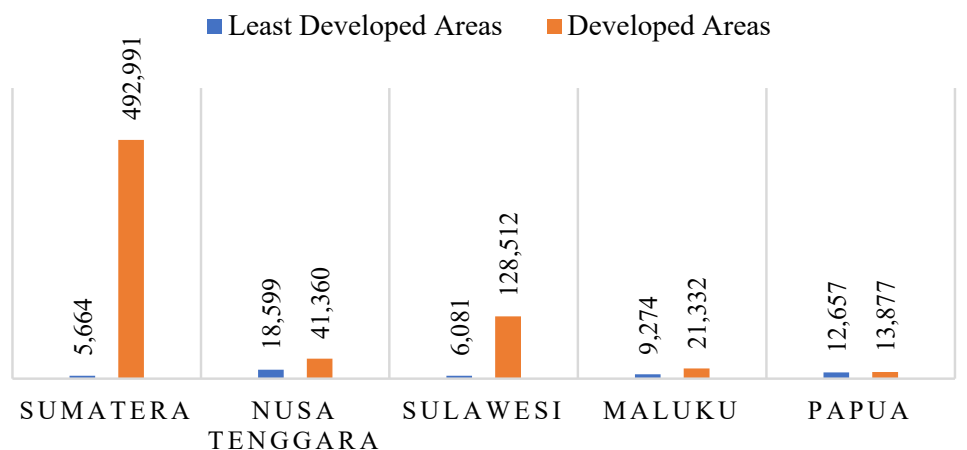

Fig 6. Distribution of the Number of ASN Teachers in Least Developed Areas and Nonleast Developed Areas per Island Region.

The isolation of the state border area results in limited infrastructure and human resources for the apparatus in supervising the border area. In areas that become national borders, for example, many camat positions are vacant as a result of the difficulty of access and the lack of infrastructure facilities. In fact, when referring to Government Regulation Number 17 of 2018 concerning Subdistricts, the camat position in addition to having roles and duties as the subdistrict head in non-border areas, the camat in the border district can assist with supervision in the field of immigration, customs, and quarantine for crossing points that do not have PLBN status, which in its implementation is assigned by the relevant ministry or non-ministerial government institution to the regent or mayor. So in this case, the position of the camat in the national border area is very crucial for the national interest, especially in ensuring public services in the national border area.

The challenge of the country's border control function can also be observed in the performance of ASN at the Directorate General of Customs and Excise, Ministry of Finance. The implementation of the 7 x 24-hour supervisory function results in an imbalance between work-life balance. In addition, many employees who work in border areas and remote areas, but have a homebase that is far from where the employees are stationed. This places employees unable to gather with their families on assignments and has implications for the increased need for additional costs for transportation access. In other agencies, the Ministry of Health places medical personnel in hospitals and health centers in remote, border, and archipelago regions (daerah terpencil, perbatasan, dan kepulauan/DTPK) through the Nusantara Sehat (Healthy Nusantara) program. 1,717 employees on duty in 75 work units, consisting of 29 work units in the outermost and frontier areas, 34 work units in least developed areas, and 12 work units in the $3 \mathrm{~T}$ areas. 
Partisanship and sharpening of 3T areas in the fields of planning and funding as well as the implementation of development of $3 \mathrm{~T}$ areas are very important in realizing equitable and equitable distribution and welfare for ASN employees in $3 \mathrm{~T}$ areas. Existing conditions in local governments indicate that income allowances or also commonly referred to as additional employee income (tambahan penghasilan pegawai/TPP), are given vary according to the regional fiscal capacity.

This is stated in Government Regulation Number 12 of 2019, article 58 paragraph (1) that local governments can provide additional income to ASN employees by taking into account regional financial capabilities and obtaining the house of representative (dewan perwakilan rakyat daerah/DPRD) approval in accordance with statutory provisions. Matters related to the provision of TPP are determined through each regional legal product.

The provision of TPP for ASN in local governments is based on the criteria of: (1) workload; (2) place of duty; (3) working conditions; (4) scarcity of professions; (5) work performance; and (6) other objective considerations. Like the story of Yacinto Dacrus, a teacher in East Nusa Tenggara, who works on the Indonesian border with Timor Leste, earning only from salary. The condition of the house is not livable with a size of only $5 \mathrm{~m} \mathrm{x} 7 \mathrm{~m} \mathrm{x} 160 \mathrm{~cm}$. He is unable to send his children to higher education and the working conditions are limited [27]. Likewise, with Johan, a junior high school teacher at Lumbis Ogong, North Kalimantan, who works on the border between Indonesia and Malaysia. He only earns salaries and allowances with a total of Rp. 5 million. He even required a fee of Rp. 8 million for transportation took his salary in the city. Finally, every 3 months just take a salary to save costs. Health facilities are also far and limited, so they prefer to seek treatment in Malaysia which is closer [28].

\subsection{Civil Servant Management Affirmative Policy Review in 3T Region}

In an effort to accelerate national development, increase people's welfare and achieve SDGs in the $3 \mathrm{~T}$ regions, one of the key success factors is the presence of the state through the state civil apparatus. The role of ASN as a catalyst for accelerating national development, improving people's welfare and achieving SDGs in 3T areas has implications for the importance of civil servant management transformation in 3T regions. Referring to Article 132 of Law Number 5 of 2014 on ASN, mandates that ASN policies and management be implemented by taking into account the specificities of certain regions and citizens with special needs. What is meant by the specificity of certain regions are having special autonomy, conflict areas, remote areas, underdeveloped areas, border areas, and special areas.

The existing condition of civil servant management at the local government level, from the phase of preparation and determination of needs, career patterns, competency development, talent management, performance management, and welfare is still based on financial capacity and regional resources. Regarding the management of civil servant, the regional government is still faced with the challenges of dynamics and practical political interests at the local level [29]. Most local governments in the 3T regions do not have adequate fiscal capacity, given the low local revenue (pendapatan asli daerah/PAD) and only rely on transfer funds from the central government in the form of the general allocation fund (dana alokasi umum/DAU) and the special allocation fund (dana alokasi khusus/DAK) [30].

This condition is also exacerbated by the lack of attention from the central government to the development and achievement of SDGs in the 3T areas, this can be seen from the indicators of SDGs achievement in Indonesia in the SDGs Index Score issued by the UN. Actually, the GOI already has clear targets related to development achievements which are expected to accelerate backwardness in the $3 \mathrm{~T}$ area. There are five main indicators of development achievements that are expected to be realized by the end of 2024 as shown in Table 5 . 
Table 5. Development Achievement Targets in the 3T Region

\begin{tabular}{llcc}
\hline \multicolumn{1}{c}{ Indicator } & Starting Point & $\begin{array}{c}\text { Development Target } \\
2020-2024\end{array}$ \\
\hline 1. $\begin{array}{l}\text { Number of sub-districts in priority locations for state } \\
\text { borders with improved welfare and governance (sub- } \\
\text { districts) }\end{array}$ & 187 & 222 \\
\hline $\begin{array}{l}\text { 2. Average Border Area Management Index (IPKP) in } \\
\text { 18 National Strategic Area Centers (PKSN) }\end{array}$ & $\mathrm{N} / \mathrm{A}$ & 0.52 \\
3. Number of underdeveloped areas (districts) & $\begin{array}{c}122 \text { (eradicated } \\
62)\end{array}$ & 37 (stopped 25) \\
4. Percentage of poor people in least developed areas \\
$\begin{array}{l}\text { (\%) } \\
\text { 5. The average of HDI in least developed areas }\end{array}$ & $58.1(2018)$ & $23.5-24$ \\
\hline
\end{tabular}

The targets that have been formulated are expected to be able to accelerate the achievement of SDGs in the 3T areas. However, so far the development priorities carried out by the central government in the 3T areas have not shown significant achievements. Therefore, it is important to optimize the role of civil servant in the $3 \mathrm{~T}$ areas in order to accelerate the achievement of these targets.

Civil servant management in $3 \mathrm{~T}$ regions should not be confused with civil servant management in other regions, given the more complex geographical conditions and obstacles faced in $3 \mathrm{~T}$ regions as well as the heterogeneity of regional characteristics in Indonesia. Affirmative policies in the management of civil servant in $3 \mathrm{~T}$ areas must be widely opened so that development disparities and achievement of SDGs in 3T areas can be narrowed.

For more than five years after the birth of Law Number 5/2014 concerning ASN, there has been no attempt to more operationally elaborate on Article 132 of the Law. In fact, the operational elaboration of Article 132 is very open and possible given the heterogeneity of the Indonesian territory, which is very, very different from one region to another. Aspects of civil servant management in the $3 \mathrm{~T}$ area starting from the preparation and determination of needs, career patterns, competency development, talent management, performance management, and welfare must be distinguished (asymmetrically) from other areas through operational affirmative policies based on Article 132 of Law Number. 5 of 2014.

\subsection{Civil Servant Management Transformation in Accelerating the Achievement of SDGs in 3T Regions}

Of the fourteen aspects of civil servant management listed in Article 2 of Government Regulation Number 11 of 2017 concerning Civil Servant Management, there are at least six main aspects that are of concern, namely: preparation and determination of needs, career patterns, competency development, talent management, performance management, and welfare, which until now still looks rigid and has not accommodated the conditions of regional heterogeneity in Indonesia. Indonesian territory with very heterogeneous characteristics requires civil servant management policies that do not generalize all, as is the case in urban areas. The complex challenges, obstacles and constraints faced in the $3 \mathrm{~T}$ regions require affirmative policies in the field of civil servant management to accelerate development achievements, especially the achievement of SDGs in the 3 T regions.

Therefore, there needs to be a transformative step in the management of civil servant in the 3T area in line with the mandate of Article 132 of Law Number 5 of 2014 concerning civil servant, among others on the aspects of: 
a. Preparation and determination of needs

Civil servant recruitment in the $3 \mathrm{~T}$ area, which currently only uses the computerized assistant test (CAT) system to recruit civil servant candidates, must be opened to accommodate local communities so that they can participate in the selection process for ASN candidates. The involvement of the local community is important because it is the local community who know a lot about the characteristics, challenges, obstacles and constraints in the $3 \mathrm{~T}$ area. This recruitment system can be done by providing a portion of $20-30 \%$ of formations for local communities in the $3 \mathrm{~T}$ area.

\section{b. Career patterns}

Civil servant career development in the $3 \mathrm{~T}$ areas must be distinguished from civil servant in other areas. Civil servant in the $3 \mathrm{~T}$ areas can be given a shorter period of time to be able to improve their career so that the main positions of civil servant in the $3 \mathrm{~T}$ areas can be filled by local people or civil servant who have started their careers in the 3T areas. This of course also needs to be balanced with the capacity or competence of the civil servant concerned, but at least there is room for civil servant in the $3 \mathrm{~T}$ areas to be able to become the top leader in the region.

Then for civil servant who come from outside the $3 \mathrm{~T}$ areas, it is necessary to design the clarity of civil servant tenure in the $3 \mathrm{~T}$ areas where this can be taken into consideration for improving the career of civil servant who have served in the $3 \mathrm{~T}$ areas. The clarity of this assignment period needs to be agreed upon from the beginning of the placement or assignment by including the length of the assignment in the assignment decision letter. This can be done in a kind of tour of duty that can be used as an added value for civil servant to be able to improve their career faster after successfully completing tasks in the $3 \mathrm{~T}$ areas.

\section{c. Competency developments}

There is a very high disparity in terms of competence and capacity of civil servant in the 3T areas. The scholarship grantee/awardee from the Indonesia Endowment Fund for Education (Lembaga Penjamin Dana Pendidikan LPDP) and the Ministry of National Development Planning (BAPPENAS) as institutions that provide many opportunities for competency development in the form of educational scholarships, there is still a lack of applicants for the scholarship program which is also the less registrants who pass get educational scholarships from civil servant in the $3 \mathrm{~T}$ areas as shown in Table 6 [31], [32].

This results in the low competence of civil servant in the $3 \mathrm{~T}$ areas which has implications for the low quality of development and the quality of public services in the $3 \mathrm{~T}$ areas. Thus, affirmative policy efforts in the form of providing competency development privileges for civil servant in 3T regions must be carried out optimally, among others through ease of participating in training, lowering the graduation standard for $3 \mathrm{~T}$ regions special education scholarship participants, and giving a larger proportion to $3 \mathrm{~T}$ regions civil servant in the competency development programs that are degree or nondegree.

Table 6. Distribution of LPDP and BAPPENAS Scholarship Awardee in Indonesia

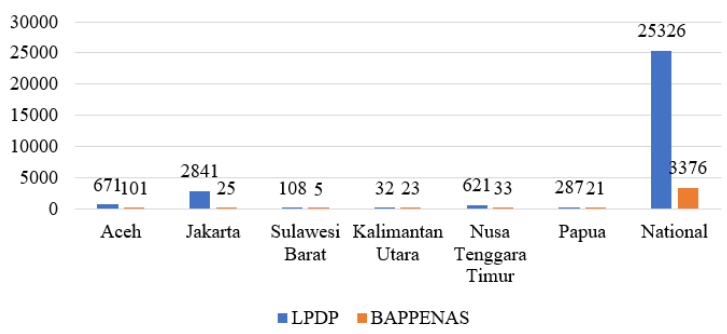


In addition, in terms of developing civil servant competencies as regulated in Regulation of National Institute of Public Administration (Lembaga Administrasi Negara/LAN) Number 10 of 2018 concerning Civil Servant Competency Development, the achievement of 20 lesson hours (jam pelajaran/JP) for civil servant competency development must be evenly distributed in all professions that support the achievement of each goal in an integrated manner.

\section{d. Talent Management}

Given the high challenges and complexity of problems in the 3T areas, superior talents are needed from civil servant to be able to solve development challenges and problems in the $3 \mathrm{~T}$ area. Therefore, civil servant who are placed in the $3 \mathrm{~T}$ areas are superior talents who are expected to be able to solve development problems and the achievement of the SDGs, so that the implication must be given an attraction so that superior talents want to actualize themselves in the $3 \mathrm{~T}$ area, one of which is by raising one grade level positions in the same position in other areas. Working in the $3 \mathrm{~T}$ areas should be a prerequisite for future leaders in the bureaucracy. The image of working in the $3 \mathrm{~T}$ areas has been seen as a dumping ground, it must be changed. Rebranding is needed to make a good impression to work on 3T areas.

\section{e. Work management}

In an effort to improve the quality of civil servant in the 3T area and answer the problems of civil servant performance management related to the lack of specialists (civil servant with special skills) and the increasing push for a functional-based bureaucracy in Indonesia according to President Jokowi's directives, it is necessary to encourage civil servant with the status of implementing towards functional positions to be more professional and have specific skills so as to improve government performance and improve the quality of public services in $3 \mathrm{~T}$ areas. In addition, encouraging civil servant to functional positions can also optimize bureaucratic patterns that are agile, not hierarchical, and silos so as to create a bureaucratic culture that is fast, effective and efficient in addition to having implications for the income of civil servant because they get job allowances and increase the class of the position concerned as in Figure 7 [33], [34].

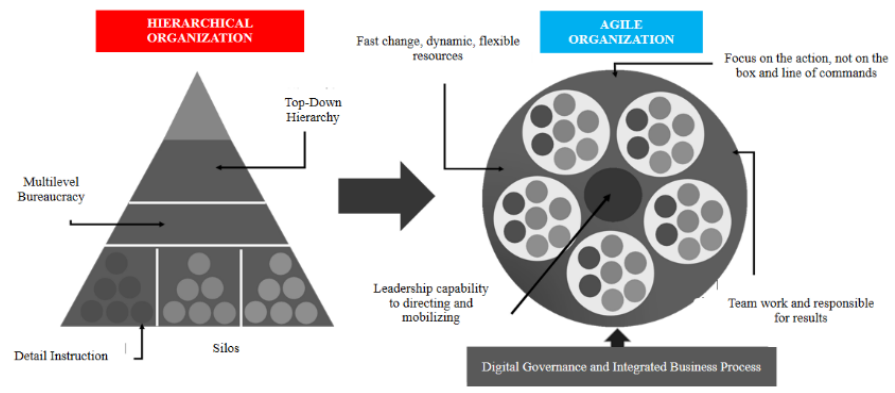

Fig. 7. Shifting from a Hierarchical Organizational Structure to an Agile Organization

\section{f. Well-being}

The aspect of financial welfare is an aspect that cannot be negated for civil servant in the $3 \mathrm{~T}$ areas. The attraction through improving the welfare of civil servant in the $3 \mathrm{~T}$ areas becomes a magnet for civil servant to want to actualize themselves in the 3T areas. Therefore, the welfare of civil servant in the $3 \mathrm{~T}$ areas must be distinguished from that of civil servant in urban areas given the challenges and severe topographical constraints. Incentives for civil servant in the $3 \mathrm{~T}$ 
areas need to be given nominally according to the regional cost index as issued by the BPS which is multiplied by the basic salary per month or providing an expensive allowance of $1 \mathrm{x}$ basic salary per month or calculated based on the Regional Cost Index multiplied by the basic salary per month.

Through the transformation of civil servant management in the 3T areas, especially in the six aspects, it is hoped that it will be able to accelerate the development targets and the achievement of the SDGs, especially in the 3T areas and the accumulation of the achievement of the SDGs nationally in general. This refers to the desired output, benefit and impact in the SDGs. In particular, there are achievements of the SDGs that are directed to the beneficiaries of the community, without any of them being left behind. Namely ending all forms of poverty, eliminating hunger, ensuring a healthy life, ensuring the quality of education, achieving gender equality, and ensuring the availability of clean water and sanitation. resilience, inequality reduction, inclusive settlements, sustainable production and consumption, rapid action to address climate change, marine resources and terrestrial ecosystems. The expected development process (which is aimed at) is to strengthen an inclusive and peaceful society and strengthen partnerships.

For example, in achieving the 2nd goal of the SDGs in the 3T areas, namely without hunger, the civil servant management aspects that cover the 2 nd goal must be transformed. In the aspect of determining the needs and recruitment of civil servant, it should be prioritized to recruit competent local people to become nutritionists, agricultural extension workers and other relevant professions to realize the achievement of the no hunger goals by providing formations for local communities by $20-30 \%$.

Professions that support the achievement of the 2 nd goal (without hunger) in the $3 \mathrm{~T}$ areas should be given the privilege of faster career development according to their competencies. In addition, a tour of duty policy is carried out with clear assignments for these professions with career advancement rewards upon returning from assignments from the $3 \mathrm{~T}$ areas.

It is necessary to make an affirmative policy for civil servant in the $3 \mathrm{~T}$ areas that supports the achievement of the 2 nd goal in order to be able to access competency development programs both degree and non-degree, including the achievement of $20 \mathrm{JP}$ which is integrated for professionals who support the achievement of the 2 nd goal such as nutritionists, agricultural extension workers, and others.

In the aspect of talent management, it is essentials to place nutritionists, agricultural extension workers and other professions that support the 2nd goal with the best qualifications in the 3T areas where they are given compensation for position 1 level higher than where they originally served. This effort is expected to be able to attract the best talents to be able to actualize themselves in the 3T area and can accelerate the achievement of the 2 nd goal.

Mapping and expanding the specific professions are needed to accelerate the achievement of the 2 nd goal (without hunger) in the $3 \mathrm{~T}$ areas. The specific professions referred to are professions that are included in the functional position group because they have specific expertise/skills in their field, professions that support the achievement of these 2nd goal include nutritionists, agricultural extension workers, nutrition specialists, etc. Other technical positions to support in macro level are needed immediately in the era of equalization and mainstreaming of agile organization in $3 \mathrm{~T}$ areas in the context of accelerating development policies from the central/regional government which then leads to excellent public services are: (a) planners; (b) policy analysts; (c) drafters of laws and regulations; (d) statistician; (e) public service complaint analyst.

Agile bureaucracy with its lean structure and rich function becomes a paradigm of change and new values in bureaucracy. Functional positions as the backbone and motor of the 
bureaucracy is required to quickly adapt to the times. In the ideal bureaucracy composition model-built organizations are encouraged to prioritize and optimize the roles and functions of specialist which are bigger than structural and administrative positions. The proportion of administrative positions in the future is expected to be no more than $10 \%$ [35]. Strengthening the role and portion of specialists through PPPK is one of the breakthroughs.

Welfare aspect playing important role to enhance motivation and performance of ASN. It is necessary to have a different income by increasing the income of civil servant in the 3T areas according to the regional cost index issued by BPS multiplied by the basic salary per month or providing an extra addition allowance of $1 \mathrm{x}$ salary per month for professions that support the achievement of the 2 nd goal. This is a form of compensation for the high price of basic necessities in the 3T areas and a form of appreciation for civil servant working in the 3T area.

The transformation of civil servant management policies, as exemplified above, must also be applied to the achievement of other goals so that the acceleration of the achievement of SDGs in the $3 \mathrm{~T}$ regions can be carried out by civil servant in the $3 \mathrm{~T}$ regions who act as catalysts for the acceleration of national development and the achievement of SDGs in the 3T regions. It is hoped that by the end of 2030, the SDGs achievement index in Indonesia will be green, which indicates that the seventeen SDGs goals have been achieved through the transformation of civil servant management in the $3 \mathrm{~T}$ regions.

\section{Conclusion}

The transformation of civil servant management in the 3T areas is very much needed considering this is the mandate of Article 132 of Law Number. 5 of 2014 on Civil Servant. In addition, the role of civil servant as a catalyst for accelerating national development and achieving SDGs in 3T regions is a determinant of the success or failure of achieving SDGs in $3 \mathrm{~T}$ regions. The transformation of civil servant management in the $3 \mathrm{~T}$ area is focused on six aspects of civil servant management, namely: (1) preparation \& determination of needs; (2) career pattern; (3) competency development; (4) talent management; (5) performance management; and well-being. It is hoped that the transformation of civil servant management in these six aspects will be able to accelerate the achievement of SDGs in the 3T regions, which are still lagging behind compared to other regions in Indonesia whose accumulation is able to increase the achievement of SDGs nationally in Indonesia until the end of 2030.

Acknowledgments. We wish to gratefully acknowledge the main supporter of this project, Head of Human Resource and General Bureau LAN, Yusuf Gunawan Idris, and Head of Center for State Civil Apparatus Management Studies LAN, Yogi Suwarno. We also want to thank Adhani Abdullah, Febby Ramadhani, and Sri Wahyu Wijayanti for contributions to support our participation on The Third International Conference Administration Science (3rd ICAS 2021).

Authors' contributions. All authors contributed substantially to the methods, intellectual content of the review, and writing and finalisation of the manuscript. All authors read and approved the final manuscript.

\section{References}

[1] United Nations: Transforming Our World: the 2030 Agenda for Sustainable Development. pp. 1-41. United Nations, US (2015) 
[2] Government of Indonesia: Rencana Pembangunan Jangka Menengah Nasional 2015-2019. Book I, pp. 3-15. Government of Indonesia, ID (2015)

[3] Sachs, Jeffrey D., et al.: Sustainable Development Report 2021: The Decade of Action for the Sustainable Development Goals. Includes the SDGs Index and Dashboards. pp. 10-11. Cambridge University Press, UK (2021)

[4] Panuluh, S., \& Fitri, M.R.: Perkembangan Pelaksanaan Sustainable Development Goals (SDGs) di Indonesia. September 2015-September 2016. pp. 1-25. International NGO Forum on Indonesia Development, ID (2016)

[5] Alisjahbana, Armida S., \& Murniningtyas E.: Sustainable Development Goals in Indonesia: concept, target and implementation strategy. pp. 40. UNPAD Press, ID (2018)

[6] Google: Google Trends with search terms: "Bureaucracy Simplification", and custom time range: "21 December 2010 - 30 June 2021", on 30 June 2021 at 09:18 WIB. Google, ID (2021)

[7] Government of Indonesia: Perpres No. 18 Tahun 2020 tentang RPJMN 2020-2024. Book III, pp. 315. Government of Indonesia, ID (2020)

[8] Ministry of National Development Planning/BAPPENAS: 3T Regional Development Strategy and Improvement of ASN Welfare in 3T Regions. pp. 1-32. Director of Disadvantaged Regions, Transmigration and Rural Areas BAPPENAS, ID (2020).

[9] National Institute of Public Administration/LAN: Welfare Incentive Model for Civil Servant in the 3T Region. pp. 4. Center for State Civil Apparatus Management Studies LAN, ID (2020)

[10] UNDP Global Center for Public Service Excellence. Motivation of public service officials: Insights for practitioners. UNDP Global Centre for Public Service Excellence Report, (3). pp. 1-24. UNDP, US (2014)

[11] Lehmann U., et al.: Staffing remote rural areas in middle- and low-income countries: A literature review of attraction and retention. BMC Health Serv Res. 2008; 8: 19. pp. 1-10.BioMed Central, UK (2008)

[12] Patro, C. S.: Employee Welfare Measures in Public and Private Sectors. International Journal of Service Science, Management, Engineering, and Technology, 6(1). pp. 22-36. IGI Global, US (2015)

[13] Hasibuan, M.S.P.: Manajemen Sumber Daya Manusia. Bumi Aksara, ID (2011).

[14] Perry, J. L., et al.: Back to the future? Performance-related pay, empirical research, and the perils of persistence. Public Administration Review January | February 2009. pp. 39-51. Wiley-Blackwell, US (2009)

[15] Druskienè, A., \& Šarkiūnaitè, I.: Motivational incentives of civil servants in Lithuanian municipalities. Public Policy and Administration, 17(3). pp. 344-370. Viešoji politika ir administravimas, LT (2018)

[16] Mukherjee, R.: Total Rewards for Civil Servants. PREM Network. pp. 1-6. World Bank, US (1998)

[17] National Institute of Public Administration/LAN: Welfare Incentive Model for High Performing Civil Servant. pp. xiii. Center for State Civil Apparatus Management Studies LAN, ID (2020)

[18] Adams, O., \& Hicks V.: Pay and non-pay incentives, performance and motivation. Paper Prepared for WHO Global Health Workforce Strategy Group. pp. 1-25. WHO, CH (2000).

[19] Efendi, F., et al.: What Do Indonesian Nurses Want? Retaining Nurses in Rural and Remote Areas of Indonesia. Online Journal of Rural Nursing and Health Care, 14(2). pp. 32-42. Rural Nurse Organization, US (2014)

[20] Sutrisnawati, N. N. D., et al.: Motivation of Strategic Health Workers to Work in Remote, Border, and Outer Island Areas (RBOIA) of Indonesia. KnE Life Sciences, 4(1). pp. 237-247. Knowledge E, AE (2018)

[21] You, Y., \& Zhang, G.. : The Political Economy of Civil Service Pay in China: A Panel Data Analysis. Chinese Political Science Review, 1(2). pp. 248-267. Fudan University and Springer Science+Business Media, SG (2016)

[22] Government of Queensland Australia: Schedule A : Remote and Regional Incentives Summary. pp. 1. Queensland Government, AU (2020)

[23] Bhatti, Z. K., et al.: Overcoming Shortages of Skilled Civil Servants in Remote and Hardship Areas. 12. pp. 1-4. World Bank, US (2019). 
[24] Ministry of Internal Affairs and Communications/MIC of Japan: Remuneration of the Japanese National Public Employees. pp. 6. MIC Japan, JP (2011)

[25] Arikunto, S.: Research Methodology. pp. Rineka Cipta, ID (2002).

[26] State Civil Servant Agency/BKN Indonesia: Data for High-Performing ASN, High-Risk and the $3 T$ Regions. pp. 1-18. Deputy for Personnel Information Systems BKN, ID (2020)

[27] Kompas: Yacinto Dacrus: Serving the Frontier. Kompas Daily, August 18th 2020, pp. 16. Kompas, ID (2020)

[28] NET TV: Portraits of Life at National Borders. Youtube Official NET News, August 16th 2016. NET TV, ID (2016)

[29] Interviews with the Head of the State Border Sub-district in Nunukan Regency, North Kalimantan Province and the Head of the State Border Sub-district in Kapuas Hulu Regency, West Kalimantan Province on August $11 \& 14,2020$ virtually.

[30] Interview with Secretary of Regions in the Region 3T ( Secretary of the Regional District of Coastal West, Province of Lampung; District Tojo Una-Una, Province of Central Sulawesi; District IslandsTaliabu, Province of North Maluku) on August 31, 2020 virtually.

[31] Indonesia Endowment Fund for Education/LPDP: Scholarship for ASN in 3T areas. Presentation by LPDP on October 16th, 2020. pp. 1-15. LPDP, ID (2020)

[32] Ministry of National Development Planning/BAPPENAS: Scholarship for ASN in 3T areas. Presentation by Pusbindiklatren BAPPENAS on October 16th, 2020. pp. 10-11. Pusbindiklatren BAPPENAS, ID (2020)

[33] Aghina, W., et al.: The five trademarks of agile organizations. pp. 1-22. McKinsey\&Company, US (2017).

[34] Ministry of National Development Planning/BAPPENAS: Formulation of Achievement Indicators for the Smart Governance/Smart ASN Module Towards World Class Bureaucracy in the New Capital City. pp. 8. Directorate of State Apparatus BAPPENAS, ID (2021)

[35] Kurniawan, A., \& Simandjorang, B.M.T.V.: Utilization of Functional Positions in the Implementation of Making Indonesia 4.0. Journal of Research and Development of Science, Technology, Social, Economy, and Culture Development Issue 03 Number 03, July 2020. pp. 57-76. Research and Development of West Lampung Regency Government, ID (2020) 